\title{
Sources of Law in a Religious Legal System: Common Paradigm Behind External Differences
}

\section{目 Alexander A. Vishnevskiy}

Professor, Department of Civil and Business Law, Law Faculty, National Research University Higher School of Economics, Doctor of Juridical Sciences. Address: 20 Myasnitskaya Str., Moscow 101000, Russia. E-mail: aavishnevsky@mail.com

\section{昰国 Abstract}

The article analyses the different sources of religious legal systems, principally the sources of the canon law of the Christian church, and it discovers a common paradigm shared by the seemingly different sources of different religious legal systems developed within the Judeo-Christian Biblical legal tradition. The author analyses, on the one hand, the decretal letters of the popes, which formed the main part of the medieval corpus of canon law in the Western Church; and, on the other hand, the writings of the Holy Fathers in conjunction with the imperial legislation and the canons of the Church Councils in the Eastern Church. This analysis elucidates a common paradigm for both traditions of canon law, which may be characterized as an 'authoritative-instructive' paradigm. The article shows that the instructive 'pole' within that paradigm is a distinctive feature of a religious legal system as such, and goes on to demonstrate its existence in the predecessor of the Christian legal tradition-Jewish law--and to outline similar features in such sources of Jewish law as rabbinic rulings, the King's Law (the enactments of secular rulers in the context of the Halakha) and the responsa. The key point is that the common paradigm expresses itself in a seemingly different manner mostly in response to external factors-the political, social, and cultural differences between the societies in which each respective system of religious law operates-and not because of religious or theological differences in the actual teachings of the religious legal systems.

\section{0표를 Keywords}

Canon law, Jewish law, church, religious legal system, sources of religious law, legal traditions.

Citation: Vishnevskiy A.A. (2017) Sources of Law in Religious Legal System: Common Paradigm behind External Differences. Pravo. Zhurnal Vysshey shkoly ekonomiki, no 4, pp. 46-58 (in English)

JEL: K10

DOI: $10.17323 / 2072-8166.2017 .4 .46 .58$

It can be taken as a settled fact that the sources of law in different religious legal systems substantially differ from each other. Our thesis is that there is a common paradigm behind this apparent diversity.

Let us consider the canon law of the Christian church. The historical development of canon law split into two main traditions-Western canon law and Eastern canon law, or Catholic and Orthodox canon law ${ }^{1}$. This dual path of development was not present from the very beginning

${ }^{1}$ One can challenge the accuracy of this statement based on the existence of Catholic canon Law of the Eastern churches. Although that is true, for the purposes of this article it seems reasonable to disregard the marginal traditions of canon law. 
of the history of canon law. Initially the Ancient Church created a common corpus of canons applicable to the whole church, which consisted of the canons of the Church Councils. These were specifically:

- canons of the Ecumenical Councils: First Council of Nicaea in 325 CE, the First Council of Constantinople in 381, the First Council of Ephesus in 431, the Council of Chalcedon in 451, the Second Council of Constantinople in 553, the Quinisext (meaning the fifth and sixth, but not considered ecumenical in the Eastern Church because no canons were adopted) in 692, the Third Council of Constantinople in 680-681, and the Second Council of Nicaea in 787;

- canons of certain provincial councils, including Ancyra, Gangra, Neo-Caesarea, Antioch, Laodicea, Sardica, and Carthage;

- the so-called Apostolic Canons, a selection of 85 rules on church discipline and organization that derive their name from the traditional understanding that these canons were devised by the apostles themselves and conveyed to Pope Clement I.

These canons touched upon a rather wide range of issues, such as Church hierarchy including sacred hierarchy (bishops, presbyters, deacons) and Church organization (separate churches headed by bishops, metropolitan provinces headed by metropolitans); questions of discipline concerning the clergy and the laity; the matrimonial law of the Church; certain aspects of the monastic life; and finally, numerous issues surrounding heresies, ecclesiastical crimes and ecclesiastical courts. All these canons formed the foundation of the legal agency of the Church and of the later development of canon law.

But this initial corpus developed differently in the East and in the West, and our thesis is that these differences are in fact different manifestations of processes common in substance.

These differences are evident in many respects, and one of them is the difference in the sources of law. Although this difference is not absolute, insofar as both traditions are based on sacred scriptures (the Bible, mostly the New Testament), as well as on the canons of the Ancient Church (jus antiquum), it is still substantial. It might even be stated that various courses and textbooks on canon law ${ }^{2}$ take these differences and a substantial degree of conflict between them for granted. And it is true that in our own era the Roman Catholic Church has a code of systematized canon law which is absent from the Orthodox tradition. ${ }^{3}$ During the Middle Ages and even earlier we find papal decretals in the West and the rules of the Holy Fathers ${ }^{4}$ in the East. From an external viewpoint, there are different sources of canon law in the Eastern and Western traditions.

There is more than just a difference in the sources of canon law. That difference has played a vital role in the very process of distinguishing the two traditions of canon law and in the very formation of those two traditions. The difference between the two traditions did not begin in the 11th century when the two churches are customarily said to have separated, at least in an

2 See, e.g.: Suvorov N.S. Uchebnik tserkovnogo prava [Textbook of Church Law]. Moscow, 2004; Tsypin V. Kanonicheskoe pravo [Canon Law]. Moscow, 2009; Nikodim. Pravoclavnoe tserkovnoe pravo [Orthodox Church Law]. Saint Petersburg, 1897.

3 Sometimes the so-called "Rule Book" - the collection of Canons of the Ancient Ecumenical Councils of the Church is referred to as the "code" of canon law in the Orthodox tradition, but from the point of view of legal theory, whether secular or and religious, it remains just a collection of the canons and not a code because it completely lacks a systematic nature and remains a mere chronological collection of the rules adopted by the Councils.

4 The Holy Fathers - also the Fathers of the Church are the writers and bishops of the first centuries of Christianity distinguished with holiness, whose writings have influenced the Christian doctrine and Canon law development. In the matters of Canon law the writings (Rules) of Basil the Great, the Archbishop of Caesarea Cappadokian is of prominent importance. 
official sense $\mathrm{s}^{5}$. The difference started to unfold much earlier, and the first substantial evident manifestation of that difference was precisely the difference in the sources of canon law as the Western and Eastern traditions established their own unique sources of canon law, which will later evolve into different structures and different approaches in religious legal systems. This process, by the way, has been taken by both churches as an additional ground to accuse each other of deviation from ancient traditions.

In spite of all these differences, and taking them all into consideration, we insist on a common paradigm behind them, which means that what looks different in substance on the surface is a differing manifestation of a similar process.

Let us begin with the external marks of this difference, which are the papal decretals in the West and the constitutions of the emperors and the rules of the Holy Fathers in the East.

Decretals (in early times also called constitutions) are understood in canon law as the decision of the popes in the form of letters addressed to the whole Catholic Church or to particular churches or persons, in most cases on matters of discipline. The decretals served as the most important sources of canon law in the medieval Western world. The official compilation of medieval canon law in the Roman Catholic Church, the Corpus juris canonici, has been divided into two parts, the first of which was Gratian's Decretum (we shall refer to it later), while the second consisted of the various and numerous papal decretals arranged in five books. The first book of 43 titles considered the sources of canon law, selection of candidates for and ordination of the clergy, different offices in the Church, contract law, property and Church property. The second book (30 titles) considered various procedural issues in the ecclesiastical courts, including status of the judges, evidence, presumptions, and appeals. The third book (50 titles) considered the discipline of the clergy, including rules of behavior, celibacy, Church benefices, the property of the clergy, issues concerning monasteries and monastic life, and Church immunities. The fourth book (31 titles) was devoted to the matrimonial laws of the Church, including legal consequences of engagement and marriage, impediments to marriage, clandestine marriages, the legal consequences of adultery, illegitimate children, and the property of spouses. Finally, the fifth book (51 titles) was involved with issues in regulating the penal law of the Church. This brief description is enough to demonstrate that papal decretals really formed a substantial, and even the most substantial part of medieval canon law in Western Europe. At times experts in canon law in medieval Europe have even been called the decretists.

The traditional explanation of the origins of the decretals is the ancient usage according to which the bishops of the western part of the Roman Empire were accustomed to refer complicated questions about the Church to the bishop of Rome. That practice in its turn is rooted in another traditional understanding of the special role designated by Jesus for the first bishop of Rome, the Apostle Peter, who had received from Jesus the authority 'to bind and to release'(ligandi solvendique), thus becoming first among the Apostles. Because the Apostle Peter became the bishop of Rome, his successors-the popes of Rome-have been treated as the heirs to that authority. This made it quite natural for the bishops to approach the popes for advice and solutions in difficult matters.

This brings up an interesting point. Initially, the papal letters were exactly the documents they were supposed to be: the replies of the bishop of Rome to the other bishops, to his broth-

${ }^{5}$ Historians used to warn against a simplistic approach to the process of separation of the Western and Eastern Churches, which took place formally, in the year 1054 because the actual process appears much more complicated and even vague. See, e.g. Lebedev A. P. Istoiriia razdeleniia Tserkvei v IX, X I XI vekakh [A History of Church Division in $9^{\text {th }}, 10^{\text {th }}$ and $11^{\text {th }}$ Centuries]. Saint Petersburg, 2004. 
ers in the Church. They were letters written in brotherly style and not some sort of command from the authorities.

As is generally found in early Christian letters, the oldest papal letters are characterized by "a brotherly pastoral style". The letters did not contain rules and commands. These early Christian writers preferred persuasion, instruction, and pastoral admonitions to affirm their common faith. The letters were basically the substitutes for preaching and oral teaching.... Only in rare cases, in which problems of jurisdiction and discipline were being decided (especially the condemnation of heretics and schismatics) did the bishops of Rome use expressions taken from the vocabulary of Roman law, as the synods commonly did at that time. The synods were the only legislative bodies in the Church, and they naturally employed the legislative language of the Roman law. ${ }^{6}$

More support in this regard comes from the famous Church History by Eusebius in which he refers to the general treatment of papal letters in the early church. Dionysius, the bishop of Corinth, mentions a letter from Pope Clement which is read in the churches on Sundays according to long-established usage: 'Today we celebrate the Holy Day of the Lord, and we have read out your letter, which we shall always read for our education as we did the earlier letter, sent to us by Clement.' The letter from the pope is read for our education, and that is natural because the earlier letters from the popes, the earlier decretals, were supposed to be the letters of education and of advice. The style of these letters clearly demonstrates, that '...the popes were not under the illusion that they were creating something new with their decretals. They were convinced that through their decrees they were only reminding the Christians of the propositions and rules that had always existed under divine law. ${ }^{8}$

The situation changes beginning with the second half of the fourth century. From that time the style of the papal letter stiffens; the language of the decretals is now based upon terms like 'praecipimus', 'decernimus', 'decrevimus', 'iubemus', 'iussimus', 'mandamus', 'volumus', etc. And the general tone of the letters indicates the difference between the level of the bishop who is asking the question, on one hand, and of the bishop of Rome answering the question, on the other. The latter is obviously superior, and he is entitled not to make reference to divine law that has always existed. This shows that the bishop of Rome is in a position to interpret that law, which in fact means he is entitled to create the law.

This was a substantial change in the sources of law in the West. How does that compare with the East of the Roman Empire and the sources of law in Eastern Christianity?

There the situation also changes and arrives at new sources of law which did not exist in the early Church, specifically, the constitutions of the emperors on various ecclesiastical matters and writings of the Holy Fathers recognized as setting the rules for the Church.

The writings of the Holy Fathers are one of the oldest of the sources on early church history, and in a broad sense they are early 'Christian letters' of the kind we already mentioned in discussing the style of the early papal decretals. These letters are mostly the replies by the Holy Fathers to questions from their Christian brothers, their colleagues. The Holy Fathers held important positions in the Church hierarchy, and those asking them for clarifications were also held the rank of bishop. In answering such questions, the Holy Fathers in fact created a large number of rules that were partially based on the canons of the Church Councils but were not limited to that source. Although these letters did indeed impose rules, they still followed the style of the early Christian letters and had not yet adopted the 'command' style of the later papal decretals.

\footnotetext{
${ }^{6}$ Jasper D., Fuhrman H. Papal Letters in the Early Middle Ages. Washington, 2001. P. 18.

7 Eusebius Pamphilius. Church History. Grand Rapids, 2007. P. 4, 23.

8 Jasper D., Fuhrman H. Op. cit. P. 20.
} 
During the historical development of canon law in the East, the writings (containing the rules) of the Holy Fathers formed a substantial part of the so-called Rule Book of the Eastern Churches that also included the writings of St Dionysius and St Peter of Alexandria, St Gregory of Neo-Caesarea, St Athanasius the Great, St Gregory of Nyssa, St Gregory the Theologian, St Amphilochius, Timothy and Theophilus of Alexandria, St Cyril of Alexandria, Gennadius and Tarasius of Constantinople, and, of course, the rules of St Basil the Great, which themselves were a substantial compendium of the rules of the Eastern Church.

The laws-or constitutions-of the emperors of the Eastern Roman empire started to govern the Church after Christianity became-first in fact, and then by law-the official religion of the Roman Empire. The first and most important compilation of those rules is the Theodosian Code of the late 4th century, and during the centuries that followed a vast corpus of novellae on different aspects of the operation of the Church were created. It is remarkable that even in our own time the law of the Russian Orthodox Church still refers to the rules established by the emperors in some very important matters, e.g. in the Church's law of marriage, including impediments to marriage. Throughout the whole medieval period and until recently nomocanons were the main source of canon law in the East. Nomocanons are collections of both Church canons and imperial decrees on bearing on Church matters, and they survived even after the decline of the Eastern Roman Empire. The most famous nomocanon of the Eastern Church is the Nomocanon of Photius the Patriarch in XIV titles.

This review of the sources of canon law has thus demonstrated that:

- new sources of law that are distinct from the decrees (or canons) of the Church Councils as the most traditional source of the law of the Ancient Church appear in the Christian Church; and

- these new sources are distinct from each other in the Western and Eastern Churches.

Now the time has come to look at this question from a slightly different angle.

Though all these sources indeed appear different in the West and in the East, they can be taken as manifestations of the two traditions in the development of canon law, both of which are common to the West and the East. These two traditions are the 'instructive' tradition and 'authoritative' tradition.

These two traditions have already revealed themselves in the jus antiquum of the Church. The instructive tradition is represented by sources which contain rules while presenting these rules not as a collection of commands, but instead as the outcome of teaching, or as advice based on understanding of more profound laws, mostly of a divine nature. The style of such sources looks more like the tractatus of a theologian (or theologians) than like a code of rules. The best examples of such sources are the Didache (or 'The Teaching of the Twelve Apostles') and the Didascalia Apostolorum. Here is an example of that approach to the rules in Didache:

There are two Ways, one of Life and one of Death, and there is a great difference between the two Ways. The way of life is this: "First, you shalt love the God who made thee, secondly, thy neighbor as thyself; and whatsoever thou wouldst not have done to thyself, do not thou to another." Now, the teaching of these words is this: "Bless those that curse you, and pray for your enemies, and fast for those that persecute you. For what credit is it to you if you love those that love you? Do not even the heathen do the same?" But, for your part, "love those that hate you," and you will have no enemy.

Indeed, the rules are presented as teaching. The same is true with regard to the other parts, as well as in the Didascalia Apostolorum, which is regarded as a kind of 'code' of canon law for the very early Church. The very name of the document reveals this understanding of it. Its full title is 'The Catholic Didascalia that is Teaching of the Twelve Holy Apostles and Disciples of

\footnotetext{
9 The Didache. A Commentary by K. Niederwimmer. Minneapolis, 1998. P.73.
} 
Our Saviour. ${ }^{10}$ The rules in this document are not merely stated; they explain themselves, for example: 'And let a woman also be subject to her husband, because the head of the woman is the man, and the head of the man that walks in the way of justice is Christ.'11

As for the authoritative tradition, it is represented in early canon law by the Apostolic Canons and later by the canons of the provincial and ecumenical church councils. Although there are doubts about the true origin of the so-called Apostolic Canons-about whether they really come from the Apostles-they do not matter for us inasmuch as they do represent the 'ruling' or what we have called the authoritative tradition, the imperium of the Ancient Church regardless of how they originated. This authoritative aspect applies in at least two areas.

First, the canons - both of the Apostles and also those issued by the councils of the Churchare formulated as strict rules, not as teaching. They do not require understanding; they require obedience, sometimes under threat of punishment.

Second, from the First Ecumenical Council in Nicaea in 325, the emperor was present so that from the very beginning authority, political authority, was embedded in the way the councils functioned. And this added political, authoritative weight to the councils themselves. Subsequently, canons of the councils were confirmed by decrees of the emperors.

The foregoing argument justifies us in stating that the sources of canon law in the Christian Church, from the very beginning and during the Middle Ages, may be grouped into two opposing elements, one of which is instructive in nature, while the other is authoritative.

It is interesting to note how Gratian's Decretum, which is perhaps the most authoritative source for the study of canon law in the Middle Ages, understood and explained this underlying structure in the appearance and development of the sources of canon law. In comparing the legal force of the papal decretals and the writings of the Holy Fathers explicating the Bible, Gratian says the following:

Decretal letters are thus legally equivalent to the canons of the councils. There remains the question of whether expositions of sacred Scripture are equal or subordinate to these. For, when someone draws on greater knowledge, it seems that his words are of greater authority. Furthermore, many writers seem to be more secure because, being filled with the Holy Spirit, they excel others in knowledge. Whence, it would seem that the opinions of Augustine, Jerome, and other writers are to be preferred to the enactments of some pontiffs.

But it is one thing to decide an issue, and another to expound the sacred Scriptures accurately. For in determining a matter, not only knowledge is necessary, but power as well. Thus Christ said to Peter [Matt. 16:19]: 'Whatever you bind on earth is bound on heaven...' before he gave him the keys of the kingdom of heaven, by the one key giving him the knowledge to discern between leper and leper, and by other giving him the power to cast people from the Church or receive in it. Therefore, when any matter is settled, whether by acquittal of the innocent or condemnation of the guilty, the acquittal or condemnation requires not only knowledge, but also the power of presiding. It is evident, that writers on the sacred Scriptures, although they surpass pontiffs in knowledge and so are to be preferred to them in questions of scriptural interpretation, take second place to them in deciding cases since they have not been elevated to the same high dignity. ${ }^{12}$

It is remarkable that Gratian considers this question at the last stage of his treatment of the sources of canon law, after he has compared the legal force of the papal decretals to any other sources of canon law, meaning that the teaching or instructive element in the source of

${ }^{10}$ Didascalia Apostolorum. The Syriac version translated and accompanied by the Verona Latin fragments with an Introduction and Notes by H. Connolly. Oxford, 1969.

11 Ibid. Chapter III, i.8.

12 Gratian. The Treatise on Laws (Decretum DD. I-XX). Washington, 1993. P. 84-85. 
canon law as represented by the Holy Fathers appears to be the 'last resort', the strongest potential opponent to the legal force of the papal decretals. This confirms our statement that the 'instructive' and 'authoritative' elements form the initial inner structure which manifests itself as different 'visible' sources of canon law and that the manifestation may take different visible shapes depending on the opposition between the instructive and authoritative elements in each particular case.

Let us illustrate or clarify what has just been said with some examples.

The papal decretals contain both of the source elements of canon law, the instructive and the authoritative components. In historical perspective, as we mentioned above, the papal decretal was born as teaching directed at fellow bishops in response to questions put by them. Later it became more and mostly authoritative both in style and in its legal force. But even in the classical period of Western canon law when papal decretals had become the most important source of law, they still retained the teaching element insofar as the texts of many decretals contain references to the sacred teachings. Although in later times the papal decretals kept their authoritative style, they also included papal teaching based partly on the right of the popes to teach on behalf of the Church and to interpret Christian doctrine officially.

In other words the papal decretals, which for most of the history of the Catholic Church have remained the main source of its canon law, always contained the instructive and the authoritative elements combined in that single source of ecclesiastical law.

How does this compare with the Eastern tradition in canon law? The Eastern tradition exhibits a different opposition between the instructive and the authoritative elements in the sources of canon law for the Orthodox churches.

The instructive element is represented by the writings of the Holy Fathers, which became officially recognized as a source of Eastern canon law. The authoritative element is represented by the canons of the Church Councils along with the imperial laws on the operation and internal affairs of the Church. While the main course in the development of the sources of canon law in the West combines these two elements in a single source of canon law-the papal decretals - the development of canon law in the East separated these two elements into different sources of canon law. In other words, we may observe not only differences in the development of the sources of canon law in the East and West, but also different manifestations of the same structural paradigm for the sources of canon law-differing opposition between the instructive and the authoritative elements in canon law sources.

How did that difference come about?

The reason for the difference between East and West in this regard lies not within, but outside each church in the political and social environment in which both churches found themselves. And the reason why this difference would manifest itself as time went on is to be found in the initial task that Jesus assigned to the Apostles: to spread the Gospel throughout the world.

This task was not an easy one, and not only because of political suppression by a number of Roman emperors, not only because of a sometimes hostile environment, but also and not least because of the internal rivalries within or between the Christian communities themselves. What is Gospel? How it should be interpreted, how it should be presented, what is the true meaning of the Lord's teaching? There were different responses to these questions. Heresies and schisms afflicted the ancient Church from the very beginning, and the development of early canon law has been influenced by those factors. The majority of the canons adopted by the church councils were created because of a need to deny and condemn heretical teachings and deviations. Indeed, many canons of ancient canon law are formulated in a negative way as a condemnation of the heretical understanding of certain issues and a restoration of the correct rule. 
In other words, there was a mission to spread a common Christianity, a unanimously understood Christianity, throughout the world. In fact, neither church has succeeded in that task, and that is why there are different Christian churches. However, the Ancient Church was moving in that same direction. Accomplishing the mission required the existence of a united church organization.

For the religion of the Old Testament there was no such mission. The Old Testament does not contain any imperative that resembles spreading the Gospel, and the cultural environment of Old Testament society was generally uniform. But that is not the case when a particular religion is to be inserted into different cultures. Political authority was not required to keep Jewish society in order. The intellectual and spiritual authority of a rabbi was enough for that purpose.

The situation changes drastically when a religion is to be preached to different people in different cultural environments. The mere moral authority of a teacher is not enough for that purpose, and the support of administrative authority is inevitably necessary. This led to the aggregation of initial Christian communities into larger unions. Dioceses folded into metropolitan provinces, allowing the bishops (heads of dioceses) to communicate Church-wide in order to ensure the unity of the religion and the church organization.

This was the way in which Christianity was expanding, but this process had to take on different shapes depending on the specific features of the individual cultures in which it was to be introduced. And the political features of the different communities were of primary importance. In order to maintain sufficient authority to ensure unified teaching, the realities of existing (or non-existing) political authority could not be ignored. In the Eastern Roman Empire the emperor himself served this purpose, while in the West the absence of an emperor imposed the same duty on the successors to St Peter the Apostle. In the East a comparatively strong emperor and other strong secular powers in different states led to 'nationalization' of the Christian churches, which organized themselves as autocephalous churches (churches whose highestranking bishops were not subject to any higher bishop or ecclesiastical authority) within the national state boundaries. The Roman Catholic Church in the West had to extend itself beyond any national political boundaries, and not only beyond European ones but also beyond boundaries all across the globe. But because of the requirement to expand into different cultures, both in the West and in the East the differences between 'authority' and 'instruction' in the 'authoritative-instructive' paradigm sharpened as these two poles became more apparent. Because the leaders of the church were unable to perform the main mission of Christianity, spreading the Gospel throughout the world, by relying solely on moral authority, political authority became another necessary condition for fulfilling the Christian mission.

The sharpening of this 'authoritative-instructive' paradigm developed in a different manner in the East and in the West. The Eastern model divided its authoritative, political pole between the head of the church and the head of the state, according to the political situation in each particular state. In most cases that led to a structure in which the leader of the church shared authority with a council of bishops under the auspices of the secular leader. In the West the popes had no one with whom to share this authoritative pole and were more burdened with spreading Christianity to cultures differing from each other than was the case in the East. This resulted in an even higher level of political authority for the popes.

But here we encounter another important point, another aspect of our thesis: although Christianity has clearly exhibited these two traditions in the sources of canon law, it did not invent them. The reason for the very existence of these two traditions with their potential for their further conflicts in various ways lies deeper, and goes back to the pre-history of Christianity and to the legal predecessor of the Christianity-Jewish law. 
Let us examine sources of Jewish law such as the King's Law and rabbinic rulings.

The reason the King's Law ${ }^{13}$ containing laws governing secular matters is part of Jewish law is explained mostly by historical realities, by the necessity of the Jewish people to live without a state or to live in exile. Under those conditions it is inconceivable that the Jewish community could survive only by the rules of their religion while ignoring the secular legislation of the countries dominating them. Moreover, the Torah itself contains provisions bearing on the secular rulers. But the process involved was not merely resignation to the secular laws of the dominant states by Jewish communities or external acceptance of something as a condition of survival. The process was more profound, and the King's Law was treated as an integral part of Jewish law.

Here is the explanation of this phenomenon offered by Nissim Gerondi (Ram), one of the leading authorities on Halakha in Spain:

It is possible that they [the laws of the Torah] were concerned more with achieving goals on a higher level than social welfare, since we establish a king over ourselves for this latter objective.

But the goal of the judges and the Sanhedrin was to judge the people according to inherently true and righteous law from which the Godly will be infused into us, whether or not the well-being of society will result from it.

Consequently, it is possible that sometimes non-Jewish law may promote social welfare more than some laws of the Torah do. But we are not without recourse because of this, as whatever needs to be done to promote social welfare may be fully accomplished by the king... The function of the judges was to judge only in according to the laws of the Torah, which are inherently just, as it is written 'And they shall judge the people with due justice' [Deuteronomy 16:18], and the function of the king was to perfect the achievement of social welfare and to do whatever the times required...

This is the difference between the judge and the king: the judge is more bound by the laws of the Torah than the king, and because of this the king was cautioned and commanded to keep a copy of the Torah at hand... in other words, since the king sees that he is not bound by the laws of the Torah in the same way as judge, a strong admonition is necessary that he should not depart from the commandments... and he should not feel superior to his brethren because of the great power that God gives to him. ${ }^{14}$

Although Jewish law is regarded as different from canon law-and they are different in the very content of their rules-nevertheless, it is possible to trace an interesting similarity with the trends we have described in canon law. The relationship between the king and the judge is in certain respects similar to the relations between the ruler and the teacher, between the one who is empowered with authority, and the one who is equipped with knowledge. Both these elements are present in canon law, and they are also present in Jewish law. Both of these religious legal systems distinguish between those privileged by knowledge and those privileged to rule.

There is another aspect of that opposition in Jewish legal history. The King's Law in the history of the Jewish law is not always confined to the laws of the secular rulers of particular countries. In certain instances the religious authorities also functioned as the secular rulers of a society. For example, it was Talmudic tradition that assigned to the Babylonian exilarchs the authority of secular rulers, of kings. The rationale behind that was that the king's legislation concerns the nation as a whole. If a secular ruler is not in place, then the leaders of the nation-meaning under these conditions the religious leaders-are empowered to discharge the duties of the kings.

${ }^{13}$ We use the term 'King's Law' because it is used by authoritative experts on Jewish law, e.g. Menachem Elon in his famous four-volume book on Jewish law.

${ }^{14}$ Elon M. Jewish Law: History, Sources, Principles. Philadelphia, 1994. Vol. I. P. 56-57. 
This leads us directly to an understanding that, insofar as a society seeks to rely on religious law (as it is embodied in the sacred text of a particular tradition) and to conduct all aspects of life according to that law, there will always be an area where mere knowledge of the laws, of the sacred texts in their certain and esoteric meaning, is not enough to maintain order in society. To achieve that goal, authority is required, and the nature of that authority will follow a format that is practical in a particular historical context, such as the pope of Rome, or the secular ruler, or the religious teacher for a relatively small society. Whether in a particular historical context we have a powerful religious leader in a kind of a theocracy or some kind of relationship between the religious and secular ruler, the key questions are the existence of both instruction and authority and finding the proper balance between them. As Menahem Elon puts it, 'The wide flexibility available in the king's law to deviate from Halakhah requires extreme care to prevent the king's law from departing from the general policy and basic values of the Torah. ${ }^{15}$

But in order to arrive at this balance it is not enough to state the rules mentioned above. The rules of the sacred texts are to be interpreted according to the particular circumstances in order to make this balance possible. As a result, the Jewish legal tradition has developed vast and far-ranging rabbinic rulings-rules which come about as a result of interpretations of the Torah by teachers and rabbis.

Another phenomenon relevant to the issues considered in this article is rabbinic law, another source of Halakha and the result of interpretation of the Torah in the teachings of the rabbis (teachers). This interpretation is really a piece of art because it is not just a commonsense interpretation; it is a real science based upon thirteen principles traditionally called the thirteen canons for interpreting the Torah. Our concern here is not to describe all these canons; and perhaps it will be enough to state, following one of the leading contemporary authorities that 'these canons basically pertain to two general categories of exegesis: (a) explicative, which aims at explaining and clarifying the verses and sections of the Torah; and (b) analogical, which relates one subject to another to broaden Jewish law and find solution to new problems. ${ }^{.16}$

Consequently, there is so-called rabbinic law which is comparable in importance to the law actually written - the law as presented in the written Torah. At times there has been great difficulty in drawing a line of demarcation between a rule explicit in the Torah and its rabbinic interpretation, and at times this was because the rabbis themselves were determined to endow their interpretations with a greater legal force even than that of the written law.

Regarding the first aspect there is a controversy in the Jewish law about what is actually meant by the law as expressly mentioned in the Torah. Does it mean only the 613 prescriptions of the Torah, the mitzvoth, or does it also extend to the rules which are the direct results of their interpretations in accordance with the thirteen canons mentioned above? Renowned authorities have disagreed on this question. The school of Maimonides insisted that the results of the canonical interpretation are rabbinic law, while Nachmanides insisted that those interpretations were Biblical law unless the Talmudic teachers had specifically stated that a particular interpretation was a rabbinic rather than a Biblical law.

As far as the legal force of the rabbinic legislation is concerned, however strange it may sound, there is a strong tendency in Jewish law not only to compare and correlate rabbinic law with the written law, but also sometimes to endow rabbinic law with higher legal force than the written law, although this occurs, of course, only in particular cases or situations. In other words there is no question about putting the rabbinic law above the written law of the Torah,

\footnotetext{
15 Ibid. P. 57.

16 Ibid. P. 319.
} 
but basing a decision about a particular case more on rabbinic interpretation, or just as much as on it as on the written law has been explicitly allowed. This is not surprising because the Torah as written does not expressly state the rules for all possible cases. It requires interpretation of its written rules by knowledgeable people (rabbis) with regard to particular cases. Therefore, most of the Halakha is in fact rabbinic legislation, and insistence on the lesser authority of halakhic interpretations by rabbis would lead to the recognition that most of the Halakha does not have the desired legal force. In other words, regarding rabbinic law as equal to or even higher than the written law was a way to preserve and employ Jewish law as a functioning legal system.

Finally, Jewish law also gave rise to the responsa, the portion of Halakha derived from the answers of experts to questions put to them, mostly regarding legal decisions bearing on the social and economic life of the Jewish community. It can be compared to rabbinic law in the sense that it is also an interpretation, but interpretation for a very specific purpose-not to serve as a final interpretation of the Torah, but to be used by an interested party as evidence in a court case. The value of the responsa was its practicality and its consideration of all the details of a particular situation in order to assess it based on the principles of the written law. It is worth mentioning that in later times respondents provided answers only when an inquiry came from a judge so that there could be no abuse by tailoring a response to favour someone's interests. The practical character of the responsa has made it one of the important sources of Halakha by volume. There about 300,000 responses on particular judicial issues.

The discussion above leads us to certain conclusions.

First of all, none of the religious legal traditions discussed can limit itself to sacred text alone as a source of law. Jewish law is not limited to the Torah, canon law is not limited to the New Testament. All these religious legal traditions require interpretation of the primary sacred text to accommodate it to reality or, as the case may be, to accommodate reality to the sacred text, or both.

There is a strong tradition of instruction in religious legal systems, and that is what most clearly distinguishes them from secular legal systems. However, one may argue that secular legal systems also have a theory and an instructive basis appealing to a certain legal philosophy or theory. What then is the difference?

The difference is that the theory of a secular legal system reflects the general logic of a secular legal system. To put it simply (may be even a bit idealistically) a secular legal system is to ensure, insofar as possible, the stability and well-being of a particular society. If the legal system, or legal theory, or philosophy of law is not adequate for that purpose, it can be replaced with more suitable theories. In a religious legal system the 'theory', the sacred teaching cannot be replaced. The purpose is not to replace it with something more suitable, but to find some solution within the existing sacred knowledge, to find a solution within the sacred sources bestowed on society from 'above' and within the existing canons. This task is more challenging than inventing a new theory. Inventing a new theory might be acceptable for a secular legal system, but a religious one is supposed to find the answer within the existing sacred heritage. And that is what makes scholars so important in a religious world and what advances their importance almost to rival whatever authority is officially empowered to proclaim and enforce the rules in the religious system of law.

A good example how this operates in a religious legal system is the famous Decretum Gratiani. We've already mentioned this famous source of medieval canon law in the Western tradition, and now we should consider how it was created. The name of the Gratian's work is 'Concordia discordantium canonum' which literally means 'reconciliation of unreconciled canons'. The reason this work appeared is that by the 11th century canon law had inherited a vast 
number of canons which, if read literally, seemed to contradict each other. Gratian undertook reconciling and resolving the contradictions, not by removing any canons (such an approach would be suitable for a secular legal system) but by finding their common substance within the sacred roots of the legal canons. It was then possible to regard the contradictory canons as contradictory not in essence, but merely as exposing different aspects of the same question. This is the approach which made Gratian's achievement so important and so valuable in the history of canon law. Otherwise, his work would have been just one more opinion on the matter. Of course, such an approach was not exceptional in the Middle Ages. It was in line with the medieval scholarly paradigm. In modern scholarship the value of a work is judged by how many new ideas a paper contains, but in medieval times the approach was quite different. The value of a scholarly treatise was assessed on how many previous authorities had been cited and referred to in it ${ }^{17}$. Gratian's genius allowed him to go further in this same direction.

But to proceed in such a direction, skilled teachers and sages are necessary, equipped not only with knowledge, but also with spiritual training in the particular religious legal tradition. That kind of knowledge, spiritually nurtured and trained knowledge, grants power which raises the teachers and their teaching to a level comparable to the official religious (and sometimes also secular) authorities; and it provides the basis for the emergence of the authoritative-teaching paradigm as the underlying paradigm of development of the sources of religious law.

This requires two kinds of inputs: interpretation and enforcement. The necessity to interpret leads to the development of teachers and of a tradition of instruction, while the necessity for enforcement involves authorities - either religious, or secular, or both-in the affairs of the religious legal system.

The need to interpret the sacred texts leading to development of the instructive tradition should not be interpreted in a simplistic manner, as if a way must be found to apply the old rules which do not take modern life into account. On the contrary, the philosophy behind the instructive tradition in religious legal systems is that the sacred text is so rich that it does indeed contain the answers to all the questions of life in different times and locations. But one is supposed to be properly prepared to make such interpretations, and this requires more than learning and education. It requires training and education that builds character not only through intellectual exercises, but also through spiritual training which allows the future teacher to develop the intellectual and spiritual skills which would allow him to understand the hidden meaning of the sacred text.

The opposition between the instructive and the authoritative (or directive) elements in a religious legal system expresses itself in different models which depend not on the teaching itself, but on the political, social and cultural environment in which the religious system operates. We have seen this in the examples of Eastern and Western traditions of canon law: the model of the East is based on separation of the instructive and authoritative elements between different authorities (religious and secular), while in the West they were combined in the pope of Rome. We have tried to demonstrate that this was due not to differences in religion-neither model can be characterized as heretical-but due to the difference in political situation in the East and in the West.

In other words, our thesis is that the difference in the outer expression of the legal sources of the different religious legal systems of Biblical origin is only a different way of expressing their common internal paradigm.

It is interesting to note that religious legal systems exhibit a similarly divergent structure not only with regard to their sources, which is the subject matter of this article, but also with regard

\footnotetext{
17 See, e.g.: Gurevich A. Izbrannye trudy [Selected works]. Saint Petersburg, 2007. P. 17-262.
} 
to their institutions. In one of our recent articles we have described how similar values ascribed to marriage, such as its unity and indissolubility, form the values common to all the Biblical legal traditions and have found different legal-normative expressions in those traditions. For example, the cultural environment of a Jewish community did not require strict prohibition of divorce unlike the cultural environment of an early medieval state in Western Europe. In other words, the different normative content of religious legal systems should not be allowed to conceal their similarity in substance.

We trust that this approach to studying religious legal systems will bring us not only favourable academic results, but also moral benefits.

\section{I国 References}

The Didache (1998) A Commentary by K. Niederwimmer. Minneapolis: Fortress Press, 288 p.

Didascalia Apostolorum (1969) The Syriac version translated and accompanied by the Verona Latin fragments with an Introduction and Notes by H. Connolly. Oxford: Clarendon Press, $280 \mathrm{p}$.

Elon M. (1994) Jewish Law: History, Sources, Principles. Philadelphia: Jewish Publication Society. Vol. I, $474 \mathrm{p}$.

Eusebius Pamphilius (2007) Church History. Grand Rapids: Kregel Academic Press, 368 p.

Gallagher C. (2007) Church Law and Church Order in Rome and Byzantium: A Comparative Study. Birmingham: University of Birmingham, $279 \mathrm{p}$.

Gratian (1993) The Treatise on Laws (Decretum DD. I-XX). Washington: Catholic University of America Press, $131 \mathrm{p}$.

Gurevich A.Ya. (2007) Katerorii srednevekovoi kul'tury. Izbrannye trudy [Selected Works]. Saint Petersburg: University, pp. 17 -262 (in Russian)

Huxley A. (ed.) (2002) Religion, Law and Tradition: Comparative Studies in Religious Law. N.Y.: Routledge, $186 \mathrm{p}$.

Jasper D., Fuhrman H. (2001) Papal Letters in the Early Middle Ages. Washington: Catholic University of America Press, $225 \mathrm{p}$.

Lebedev A.P. (2004) Istoiriia razdeleniia Tserkvei v IX, X i XI vekah [A History of Church Division in 9th, 10th and 11th Ages]. Saint Petersburg: Abyshko, 352 p. (in Russian)

Nikodim, Bishop of Dalmatia (1897). Pravoclavnoe tserkovnoe pravo [Orthodox Church Law]. Saint Petersburg: Komarov, 708 p. (in Russian)

Suvorov N.S. (2004) Uchebnik tserkovnogo prava [Textbook of Church Law]. Moscow: Zertzalo, 504 p. (in Russian)

Tsypin V. (2009) Kanonicheskoe pravo [The Canon Law]. Moscow: Sretenskyi monastyr, 864 p. (in Russian)

Van de Wiel C. (2005) History of Canon Law. Louvain: Peters Press, $192 \mathrm{p}$.

Winroth A. (2000) The Making of Gratian's Decretum. N. Y.: Cambridge University Press, 245 p. 